\title{
Beneficiation of Barite Ore from Azara in Nassarawa State, Nigeria, using Froth Flotation
}

\author{
Henry E. Mgbemere*, Suleiman B. Hassan, Joshua A. Sunmola \\ Department of Metallurgical and Materials Engineering, University of Lagos Akoka, Lagos, Nigeria.
}

\begin{abstract}
Barite ore from Azara in Nassarawa State has been beneficiated using Jigging and Froth Flotation techniques by varying the $\mathrm{pH}$ of the solution. The chemical analysis indicates the presence of major elements $\mathrm{Ba}, \mathrm{S}$, $\mathrm{O}$ and minor elements like $\mathrm{Ti}, \mathrm{V}, \mathrm{Al}$ and $\mathrm{Si}$ which confirms that it is barite while the particle size analysis showed that the average particle size is $\approx 150 \mu \mathrm{m}$ with a $1,167 \mathrm{~cm}^{2} / \mathrm{g}$ specific surface area. The X-ray diffraction analysis of both the as-mined ore and beneficiated samples indicate increased intensity in the later. The jigging result shows that $51 \%$ of the feed is the underflow while $46.7 \%$ is the overflow. The measured specific gravity as a function of $\mathrm{pH}$ show that values between 3.78 and 4.23 are obtained. The elemental composition of the Barite after beneficiation shows that in addition to high contents of $\mathrm{BaO}$ and $\mathrm{SO}_{3}$, the amount of $\mathrm{SiO}_{2}$ present is still very high. The sample with a $\mathrm{pH}$ value of 7 gave the highest specific-gravity value of 4.23 while that with $\mathrm{pH}$ of 3 gave the lowest specific-gravity value of 3.78. The implication is that the barite sample with $\mathrm{pH}$ of 7 is acceptable for oil and gas applications while more work is needed for samples with other $\mathrm{pH}$ values.
\end{abstract}

KEYWORDS: Barite ore, Froth flotation, Specific gravity, Beneficiation, $\mathrm{pH}$, Jigging.

\section{INTRODUCTION}

Barite has a lot of industrial applications, but in Nigeria, it is used mainly as a drilling fluid in the oil and gas industry. The demand for Barite will increase for a very long time provided the economic activity in the oil and gas sector is sustained. The Nigerian Government placed some restrictions on the importation of barite into the country since the year 2003 to enable the local barite industry to thrive (Mills 2005). In 2013 however, the International Oil Companies (IOCs) operating in the country applied for a relaxation of the restriction on imported barite on the basis that the locally produced barite have lower quality compared to the imported ones. Multinational companies like Schlumberger, Halliburton, and Newpark, therefore, are currently the major suppliers at the rate of $\$ 300-400$ per ton (Bleiwas and Miller 2015).

The problem with the barite produced in Nigeria is that their specific gravity values are in most cases below the minimum industrially accepted value of 4.2. Attempts have been made in the past to improve the specific gravity values of barite ores from within (Achusim-Udenko et al. 2011; Onyedika and Njoku 2007; Onyemobi and Nwoko 1997) and outside (Ciccu et al. 1987; Grigorova et al. 2015; Hadjiev et al. 2000; Raju et al. 2004; Ulusoy and Yekeler 2007; Wang et al. 2014) the country. Onyemaobi \& Nwoko (1997) and Achusim-Udenko et al., (2011), beneficiated barite ore samples from Azara in Nassarawa State, Nigeria using both Jigging and Magnetic separation processes. Atomic Absorption Spectrophotometer was used to analyse the

*Corresponding author: hmgbemere@unilag.edu.ng elemental composition. $\mathrm{BaSO}_{4}$ content in the analysed head ore was found to be $98 \%$, and a comparison between Jigging and Magnetic separation processes showed that the former produces a more satisfactory result than the latter. Azara barite ore has been beneficiated using Froth Flotation process with palm fruit bunch as the collector. The raw materials used include a solution containing burnt empty palm (Eleasis guineesis) bunch and analytical grade palmitic acid as a collector with sodium silicate as the depressant. The conclusion from the research is that the use of locally available palm fruit bunch led to an increase in the concentration of the barite from 75.4 to $91.9 \%$. The final barite recovery which represents about $18 \%$ increase in assay meets the requirement for petroleum and other allied industries. The recommendation was that jigging and magnetic separation processes should be carried out before the froth flotation process. (AchusimUdenko et al., 2011)

This research is focused on the use of the jigging and the froth flotation to beneficiate Azara Barite ore to increase its specific gravity value. The intention is to investigate the effect of $\mathrm{pH}$ on the specific gravity values of barite processed using froth flotation method.

\section{EXPERIMENTAL PROCEDURE}

\section{A. Sample Preparation}

The estimate of Barite ore deposit in Azara locality of Nassarawa State in Nigeria is about 750,000 metric tonnes while the specific gravity values ranges from 3.6 to 4.0 ((RMRDC), 2010). The barite ore used for this investigation

doi: http://dx.doi.org/10.4314/njtd.v16i1.6 
was procured from Azara in Nassarawa State, Nigeria. The lumps of Barite were crushed using Jaw crushers, (Schutte Buffalo Hammer Mills) at the Minerals laboratory of Kaduna Polytechnic, Nigeria. The samples were further pulverized with a laboratory ball mill (Shambhavi Impex Ball Mill (Model No: A162)) and mixed thoroughly to achieve homogeneity. The sample was ground for 30 minutes, and then subjected to size analysis using the laboratory sieve shaker for 10 minutes. The sieve sizes used were $+355 \mu \mathrm{m},+250 \mu \mathrm{m}$, and a pan. The particle sizes varied from $-355 \mu \mathrm{m}$ to $250 \mu \mathrm{m}$ and were collected for the jigging operation. The precise size distribution of the barite powder was determined using a particle size analyser (Mastersizer 2000, Malvern Instruments UK).

For the jigging operation, $3000 \mathrm{~g}$ of the barite ore in the size range -355 to $+250 \mu \mathrm{m}$ was used to produce the pulp. This size range is believed to be good for jigging based on the experience of the operator and also with information from literature (Wills 1981). The pulp was fed into the jigging machine with constant supply of water for smooth operation. Both the overflow and underflow were decanted separately into collecting pans respectively and were allowed to settle and then dewatered. The overflow and underflow were dried in a laboratory oven for 5 hours and their weights were measured.

$1500 \mathrm{ml}$ of distilled water and $200 \mathrm{~g}$ of the overflow from the Jigging operation were fed into the laboratory froth flotation cell. The concentration of the reagent in the pulp affects the recovery process, and for best recovery, 0.010 moles/litre was used (Achusim-Udenko et al., 2011). The impeller was lowered gently into the cell and stirred for five minutes to obtain a proper suspension of solid particles within the pulp. $\mathrm{NaOH}$ and $\mathrm{HCl}$ were added to the pulp as $\mathrm{pH}$ regulators while litmus papers were used to determine the $\mathrm{pH}$ of the solution. Four drops of oleic acid was added to the pulp and then the frother which is pine oil was also added. The selected flotation time was 5 mins because it is a laboratory equipment, and this time is supported by a literature report (Metso 2006). The froth was skimmed off the flotation cell into the collecting pan until barren froth persisted. It was allowed to settle, dewatered, washed and then dried in a laboratory oven at $110{ }^{\circ} \mathrm{C}$. The depressed mineral was also dewatered, washed and dried. The froth which consists of the concentrate and the depressed mineral (tailings) were weighed and recorded. This procedure was repeated for $\mathrm{pH}$ values of $3,5,7,9$ and 10 .

\section{B. Sample Characterisation}

The chemical compositions of the raw and beneficiated barite samples were determined using X-ray Fluorescence (XRF) where the samples were pulverized. $20 \mathrm{~g}$ of the prepared sample was weighed using a weighing balance into the sample holder. The holder and its contents were carefully placed in their respective measuring positions on the sample changer. The XRF analysis was carried out with a SKYRAY INSTRUMENT: EDX3600B XRF spectrometer at the Nigerian Geological Survey Agency in Kaduna Nigeria. The samples to be analysed were maintained as loose powders and the measuring voltage used was $45 \mathrm{kV}$.
The specific gravity of the barite ore was measured before and after beneficiation to compare the effectiveness of the froth flotation process. The procedure employed included washing the sample thoroughly and then weighing it. An empty specific gravity bottle (pycnometer) was weighed and recorded. The ground sample was filled to about $1 / 3$ of the specific gravity bottle, and then both sample and bottle were weighed. The remaining space in the bottle was filled with water and weighed. The content of the bottle was discarded, the bottle filled with fresh water, and the weight of bottle determined.

The X-ray diffraction measurements were carried out with an X-ray spectrometer (GBC EMMA equipment, GBC Enhance mini-material analyser) at the Engineering Materials Development Institute Akure Nigeria. A PANanalytical (EMPYREAN B.V Netherlands) diffractometer system with $\mathrm{CuK} \alpha_{1}$ operating at $45 \mathrm{kV}$ and $40 \mathrm{~mA}$ with PIXcel-3D detector was also used at the Nigerian Geological Survey Agency, Kaduna, Nigeria. The minimum diffraction angle is $9.01313^{\circ}$ while the maximum angle is $74.97967^{\circ}$. The sample was pulverised to fine homogenous powder and loaded into the XRD for measurement.

The morphology of the sample was determined using a Scanning Electron Microscope (SEM) (Phenom Prox Scanning Electron Microscope attached with an Energy Dispersive X-ray Spectrometer (EDX) at the Engineering Materials Development Institute Akure, Nigeria. The sample was crushed to the desired size, coated with conducting carbon layer, placed on a sample holder and finally bombarded with a beam of electrons. The signals were generated through detection of backscattered electrons.

\section{RESULTS AND DISCUSSION}

\section{A. Particle Size Analysis}

Figure 1 shows the particle size distribution for the Azara barite ore before the beneficiation process. Particle sizes of powders are usually analysed using the terms $\mathrm{d}_{10}, \mathrm{~d}_{50}$, and $\mathrm{d}_{90}$ which stand for particles that are $\leq 10 \%, \leq 50 \%$, and $\leq 90 \%$ respectively. Two peaks are observed on the image; low volume peak at $0.6 \mu \mathrm{m}$ and a high-volume peak at $240 \mu \mathrm{m}$. The $\mathrm{d}_{10}, \mathrm{~d}_{50}$, and $\mathrm{d}_{90}$ values for the barite powder are $1.302 \pm 0.132$ $\mu \mathrm{m}, 149.8 \pm 5.26 \mu \mathrm{m}$ and $1167.6 \pm 57.61 \mu \mathrm{m}$ respectively while the specific surface area is $1,167 \mathrm{~cm}^{2} / \mathrm{g}$.

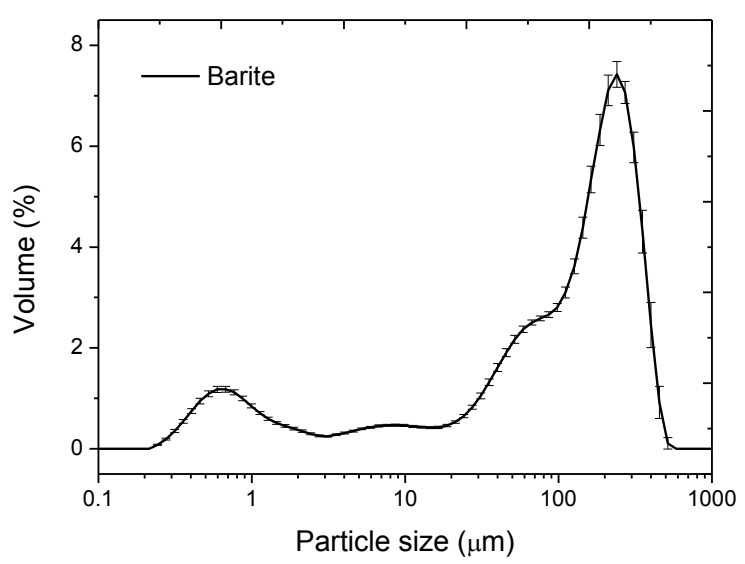

Figure 1: Particle size distribution for the Azara barite ore before beneficiation. 


\section{B. X-ray Diffraction Analysis}

The X-ray diffraction patterns for both the as-mined barite ore and the beneficiated barite samples are presented in Figure 2. The distribution in Figure 2 is comparable with the previous work on barite ore from another location (Bukkuyum, Zamfara State Nigeria. The diffraction peaks between the sample in the literature and the present work match very well (Salisu et al., 2015) further confirming that the ore sample is barite. When the barite ore is beneficiated, at $\mathrm{pH}$ of 3 , the peaks at 29,32 and $43.5^{\circ}$ respectively become more pronounced. At $\mathrm{pH}$ of 7 , the diffraction peaks and their intensities did change at diffraction angles of 25 and $26^{\circ}$ respectively. This is an indication of a possible change in the structure of the barite. At $\mathrm{pH}$ of 10 , the diffraction peaks at 32 and $43.5^{\circ}$ are no longer pronounced. This is an indication that as the sample is beneficiated, the amount of impurities decreases thereby increasing the concentration of the $\mathrm{BaSO}_{4}$.

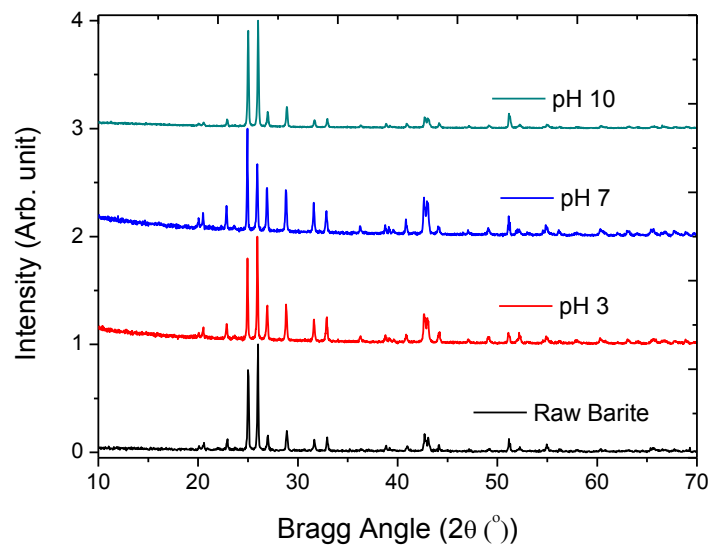

Figure 2: X-ray Diffraction (XRD) patterns of Azara Barite ore processed with different $\mathrm{pH}$ values and measured at room temperature.

Observations indicate that the $\mathrm{pH}$ value of the pulp has some effect on the diffraction patterns. The position of the diffraction peaks remained the same but with different intensities. The as-mined barite has low peak values but at $\mathrm{pH}$ of 3 , the peak value slightly increases and even higher values at a $\mathrm{pH}$ of 7 . As the $\mathrm{pH}$ further increases to 10 , the values of the peaks however decreases.

\section{Scanning Electron Microscopy Analysis}

Figure 3 shows the scanning electron microscope image of the barite ore. The Figures ( $3 a$ and $3 b$ ) reveal both the morphology of the barite powder and the energy dispersive spectroscopy (EDS) before the beneficiation process respectively. In the EDS spectra, different peaks can be observed which are associated with the major element Ba. In addition, other elements like Ti, Mo, Sn etc. are observed which represent the impurities associated with barite ores. The crystal structure of barite is orthorhombic with Pnma space group (Colville and Staudhammer 1967). Table 1 shows the result of elemental composition analysis of the barite ore using $\mathrm{X}$-ray fluorescence. It is observed that the ore contains $36.2 \%$
Barium, 34.4\% Sulphur, 14.7\% Titanium, 5.5\% Vanadium, $1.8 \%$ Aluminium, $1.5 \%$ Silicon, etc.
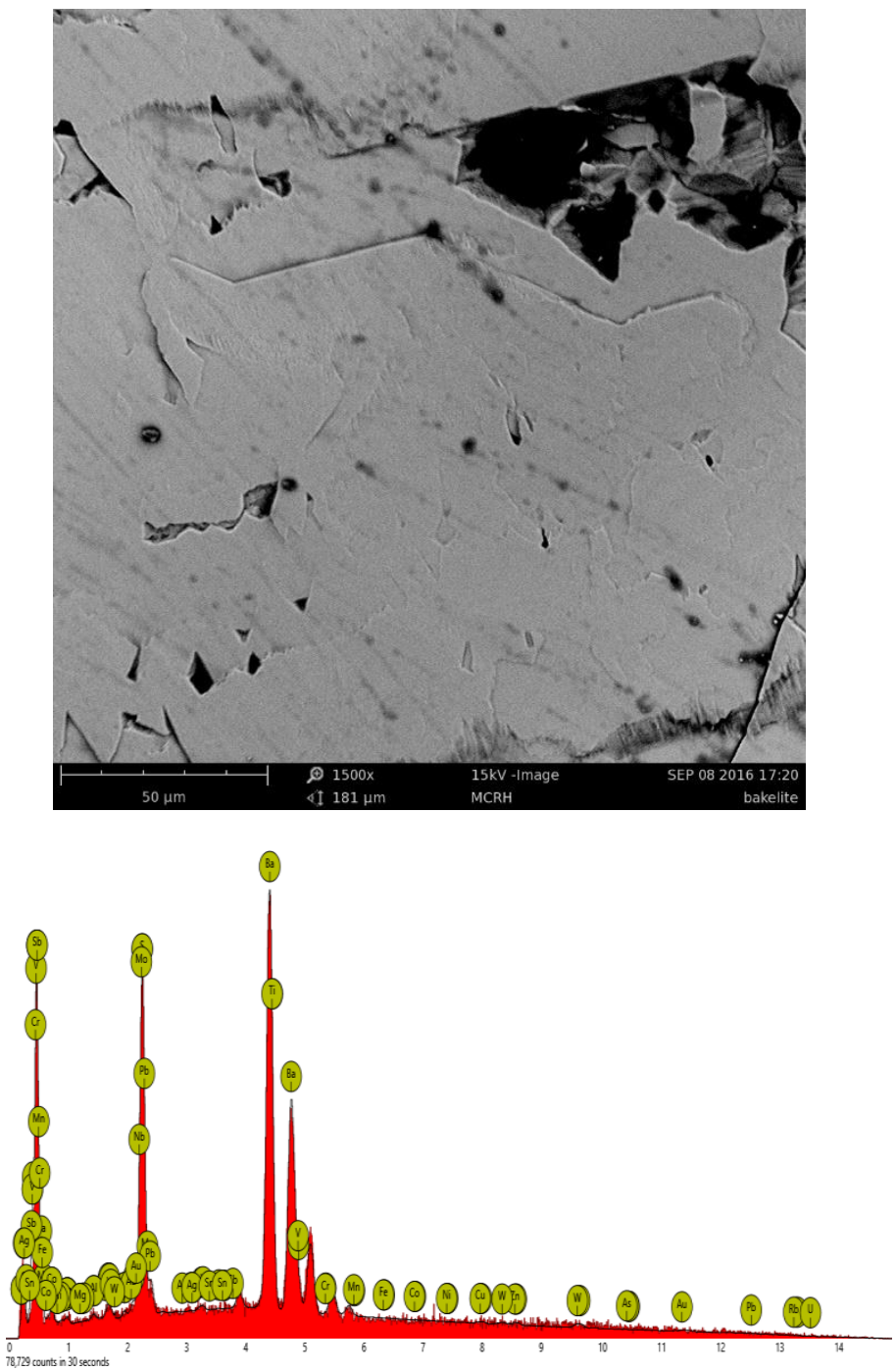

Figure 3: (a) Scanning Electron Microscope image of Azara barite ore before beneficiation, (b) Energy Dispersive Spectroscopy (EDX) showing Peak Intensities of the Elemental Composition of Azara barite ore.

The specific gravity of the barite ore before the beneficiation process is calculated using the ratio between the mass of the barite ore and the volume of the liquid displaced. The volume of liquid displaced is equal to the difference between the final and the initial volumes. The specific gravity of the barite ore was calculated using the ratio of the density of the barite to the density of distilled water. The specific-gravity value for the barite ore is $3.72 \pm 0.06$.

\section{Jigging}

The result of the jigging operation is shown in Table 2. The result indicates that $51.7 \%$ of the feed was recovered as underflow i.e. the concentrate while $46.7 \%$ was recovered as overflow i.e. the tailings. $1.6 \%$ of the feed was lost during the 
Table 1: The result of X-ray Fluorescence analysis for the Azara barite ore.

\begin{tabular}{cccccccc}
\multicolumn{2}{l}{ Table 1: The result of X-ray } & Fluorescence analysis for the Azara barite ore. \\
\hline $\mathbf{A l}$ & $\mathbf{S i}$ & $\mathbf{P}$ & $\mathbf{S}$ & $\mathbf{K}$ & $\mathrm{Mo}$ & $\mathbf{T i}$ & $\mathbf{V}$ \\
\hline 1.7642 & 1.4555 & 0.4034 & 34.4265 & 0.1448 & 0.1286 & 14.7101 & 5.4631 \\
$0.2 \pm 28.7$ & $0.3 \pm 15.4$ & - & $2.4 \pm 3$ & $0.2 \pm 30.9$ & $12.6 \pm 2.1$ & - & - \\
$\mathrm{Mn}$ & $\mathrm{O}$ & $\mathrm{Sb}$ & $\mathrm{Ba}$ & $\mathrm{Fe}$ & $\mathrm{W}$ & $\mathrm{Sn}$ & - \\
0.2913 & - & 0.2567 & 36.2004 & 0.1762 & 0.1161 & 0.2779 & - \\
- & $22.7 \pm 1.7$ & - & $50.5 \pm 1.1$ & - & $1.6 \pm 41.3$ & - & - \\
\hline
\end{tabular}

Table 2: Result of the Jigging Operation.

\begin{tabular}{cccccccc}
\hline $\begin{array}{c}\text { Sieve Size } \\
(\boldsymbol{\mu m})\end{array}$ & $\begin{array}{c}\text { Feed } \\
(\mathbf{g})\end{array}$ & $\begin{array}{c}\text { Underflow } \\
(\mathbf{g})\end{array}$ & $\begin{array}{c}\text { Overflow } \\
(\mathbf{g})\end{array}$ & $\begin{array}{c}\text { Loss } \\
(\mathrm{g})\end{array}$ & $\begin{array}{c}\text { Underflow } \\
(\boldsymbol{\%})\end{array}$ & $\begin{array}{c}\text { Overflow } \\
(\%)\end{array}$ & $\begin{array}{c}\text { Loss } \\
(\%)\end{array}$ \\
\hline 355 & - & - & - & - & - & - & - \\
-105 & 3,000 & 1,550 & 1,400 & 50 & 51.7 & 46.7 & 1.6 \\
-70 & - & - & - & - & - & - & - \\
-55 & - & - & - & - & - & - & - \\
215 & - & - & - & - & - & - & - \\
-40 & - & - & - & - & - & - & - \\
-50 & - & - & - & - & - & - & - \\
\hline
\end{tabular}

jigging operation. After the jigging process, the specificgravity was measured to be $3.75 \pm 0.09$, a $0.8 \%$ improvement when compared to the specific-gravity value of the as-mined barite sample.

\section{E. Froth Flotation}

Table 3 shows the result of the percentage recovery and specific gravity values after froth flotation process. The operation was carried out by using $\mathrm{NaOH}$ to vary the $\mathrm{pH}(3,5$, 7, 9 and 10) of the solution. Except for the samples with $\mathrm{pH}$ of 3 and 10 where the percentage recovery of the feed is $70.85 \%$ and $88.75 \%$ respectively, the percentage recovery for other samples were above $90 \%$. However, this did not translate to higher specific-gravity values. The sample with $\mathrm{pH}$ of 3 has a very high amount of depressed materials (25.2\%) compared to others where the percentage of the depressed materials were less than $9 \%$. It is possible that the highly acidic nature of the solution resulted in the removal of the main constituents in addition to the unwanted constituents. The specific gravity values for the barite with $\mathrm{pH}$ of $3,5,7,9$ and 10 are 3.78, 3.27, $4.23,3.87$ and 4.1 respectively (see Table 3 ). It is not clear why the barite with $\mathrm{pH}$ of 5 have specific gravity value lower than that of the ore. Only the barite with specific-gravity value of 7 gave an acceptable value that can be used for industrial application.
The particle size of the starting barite ore and the number of flotation cells are factors which are usually considered during froth flotation. When the particles are too fine, they may cause disruption in the flotation process and if very coarse particles are used, it becomes too difficult for the particles to be lifted through the froth. The best particle size range therefore considered in this work falls within $-350 \mu \mathrm{m}$ to +180 $\mu \mathrm{m}$ which is also inclined with the size fed into the jigging machine.

The major reaction that occurred during the froth flotation process is the reaction between the barite ore and octadec-9enoic acid as shown in eqn (1).

$$
\begin{aligned}
& \mathrm{BaSO}_{4}+2 \mathrm{CH}_{3}\left(\mathrm{CH}_{2}\right)_{7} \mathrm{CH}=\mathrm{CH}\left(\mathrm{CH}_{2}\right)_{7} \mathrm{COOH} \rightarrow \\
& \left(\mathrm{CH}_{3}\left(\mathrm{CH}_{2}\right)_{7} \mathrm{CH}=\mathrm{CH}\left(\mathrm{CH}_{2}\right)_{7} \mathrm{COO}\right)_{2} \mathrm{Ba}+\mathrm{H}_{2} \mathrm{SO}_{4}
\end{aligned}
$$

When two moles of oleic acid reacts with 1 mole of barium sulphate, the result is barium oleate (barium octadec-9-enoate) a hydrophobic monolayer which will attach to the bubbles formed. The oleic acid, when dissolved in the solution, dissociates to develop a negative charge. The negatively charged group is then attracted to a positively charged mineral surface by electrostatic attraction, the hydrocarbon chain of the oleic acid then extends out into the liquid and alters the surface hydrophobicity which attaches to the bubbles formed and

\begin{tabular}{|c|c|c|c|c|c|c|c|c|c|}
\hline \multirow[t]{2}{*}{ S/No } & \multirow[t]{2}{*}{ pH } & \multirow{2}{*}{$\begin{array}{l}\text { Wt. of } \\
\text { Froth (g) }\end{array}$} & \multirow{2}{*}{$\begin{array}{c}\text { Wt. of } \\
\text { Depressed (g) }\end{array}$} & \multirow[t]{2}{*}{ Loss (g) } & \multicolumn{4}{|c|}{ Specific Gravity } & \multirow{2}{*}{$\begin{array}{c}\% \\
\text { Recovery }\end{array}$} \\
\hline & & & & & & & & Average & \\
\hline 1 & 3.0 (acidic) & 141.7 & 50.2 & 8.1 & 3.7 & 3.8 & 3.85 & $3.78 \pm 0.06$ & 70.85 \\
\hline 2 & 5.0 (acidic) & 186.9 & 10 & 3.1 & 3.1 & 3.3 & 3.25 & $3.27 \pm 0.1$ & 93.45 \\
\hline 3 & 7.0 (neutral) & 185.8 & 12 & 2.2 & 4.15 & 4.2 & 4.25 & $4.23 \pm 0.05$ & 92.9 \\
\hline 4 & 9.0 (alkaline) & 187.3 & 8 & 4.7 & 3.8 & 3.85 & 3.95 & $3.87+0.63$ & 93.65 \\
\hline 5 & 10.0 (alkaline) & 177.5 & 17 & 5.5 & 4 & 4.15 & 4.1 & $4.1 \pm 0.06$ & 88.75 \\
\hline
\end{tabular}
makes flotation of the barite mineral effective. 


\section{F. Chemical Analysis}

Table 4 shows the chemical composition of the barite processed at different $\mathrm{pH}$ values. The amount of $\mathrm{BaO}$ in the barite to a great extent determines the specific gravity of the barite. With $\mathrm{pH}$ values of $3,5,7,9$, and 10 , the $\mathrm{BaO}$ contents are $70.45 \%, 64.7,74.5 \%, 67.75 \%$ and $73.32 \%$ respectively. The low $\mathrm{BaO}$ content in the sample with $\mathrm{pH}$ of 5 is related to the low specific gravity value that was obtained. When the amounts of the compounds which are not neither $\mathrm{BaO}$ nor $\mathrm{SO}_{3}$ are added together, they make up more than 7\%. The $\mathrm{SiO}_{2}$ contents for all the barite samples are rather high which shows that the specific gravity values can be further improved if these impurities can be further reduced.

The result from this work is compared to that from a commercial barite mining company in Nigeria (Veranum Mining and Exploration Limited Jos). The specific gravity values from this study and the commercial samples were measured three times. The $\mathrm{pH}$ of the commercial barite was measured to be 8.14 which is between the $\mathrm{pH}$ values of 7 and 9 used in this study. The commercial sample gave a specific gravity value of $4.16 \pm 0.04$ which is slightly lower than that in this research at $\mathrm{pH}$ of $7(4.23 \pm 0.05)$ but higher than that at $\mathrm{pH}$ of $9(3.87+0.63)$. The chemical composition analysis of the commercial barite is shown in Table 5 . The major constituents in this barite sample are also found in the Azara barite investigated in this work. The major constituents were found to be $\mathrm{BaO}(72.04 \%)$ and $\mathrm{SO}_{3}(19.48 \%)$. This is similar to the amounts of the major constituents in our work at $\mathrm{pH}$ of 7 which are $\mathrm{BaO} 74.5 \%$ and $\mathrm{SO}_{3} 17.6 \%$. High concentrations of silica were found in both the commercial sample and in this work

\section{CONCLUSION}

Barite ore from Azara in Nassarawa State, Nigeria, has been processed using Jigging and Froth Flotation processes. The particle size analysis showed that the average size of the particles is $\approx 150 \mu \mathrm{m}$ which is good for the jigging process. The $\mathrm{X}$-ray diffraction studies showed that barite was processed and as the impurity level decreases, the intensity of the peaks increases. The specific gravity of the barite ore before beneficiation is $3.72 \pm 0.06$ and $3.75 \pm 0.09$ after jigging. This indicates that jigging has a very small effect in this study concerning increasing specific gravity values. The lowest specific gravity value $(3.27 \pm 0.1)$ for the processed barite was at $\mathrm{pH} 5$ and highest $(4.23 \pm 0.05)$ with $\mathrm{pH} 7$. This indicates that $\mathrm{pH}$ affects the specific gravity values of barites. The chemical analyses show that the higher the $\mathrm{BaO}$ content, the higher is the specific gravity value. The amount of impurities after the froth flotation process is still high especially for $\mathrm{SiO}_{2}$ and needs to be reduced. The specific gravity values from this work compare very well with commercially available barites. This indicates that this process is suitable for producing barite at $\mathrm{pH}$ value of 7 .

\section{REFERENCES}

Achusim-Udenko, A. C.; O. Gerald, O. Martins and A. Ausaji. (2011). Flotation recovery of barite from ore using palm bunch-based collector. Int. J. Chem. Sci, 9(3):1518-1524.

Bleiwas, D. I., and Miller, M. M. (2015). Barite: a case study of import reliance on an essential material for oil and gas exploration and development drilling (No. 2014-5230). US Geological Survey.

Ciccu, R.; L. Curreli, S. Giuliani, P. P. Manca, and O. Massacci. (1987). Optimization of an integrated flowsheet for barite processing, In Twentieth International Symposium on the Application of Computers and Mathematics in the Mineral Industries. Johannesburg, South Africa.

Colville, A. A., and Staudhammer, K. (1967). A refinement of the structure of barite from cow green mine. American Mineralogist 52:1877-1880.

Raw Materials Research and Development Council (RMRDC) (2010). Non - Metallic Mineral Endowments in Nigeria. Abuja: Federal Ministry of Science and Technology.

Grigorova, I.; S. Dzhamyarov, and I. Nishkov. (2015). Barite flotation concentrate from Kremikovtzi "BLACK" tailings. Journal of International Scientific PublicationsMaterials, Methods \& Technologies 9:561-577.

Hadjiev, A.; P. Hadjiev, and R. Georgiev. (2000). Flotation of barite from complex Iron ore.

Metso. (2006). Basics in Minerals Processing - Section 4Separations, Metso Minerals, $5^{\text {th }}$ Edition, http://www.metso.com.

\begin{tabular}{|c|c|c|c|c|c|c|c|c|c|c|c|c|}
\hline pH & Compounds & $\begin{array}{l}\mathrm{SiO}_{2} \\
\text { (wt.\%) }\end{array}$ & $\begin{array}{l}\mathrm{SO}_{3} \\
\text { (wt.\%) }\end{array}$ & $\begin{array}{l}\mathrm{Fe}_{2} \mathrm{O}_{3} \\
\text { (wt. \%) }\end{array}$ & $\begin{array}{l}\mathrm{CuO} \\
\text { (wt.\%) }\end{array}$ & $\begin{array}{l}\text { ZnO } \\
\text { (wt.\%) }\end{array}$ & $\begin{array}{l}\text { SrO } \\
\text { (wt.\%) }\end{array}$ & $\begin{array}{l}\mathrm{Ag}_{2} \mathrm{O} \\
\text { (wt.\%) }\end{array}$ & $\begin{array}{l}\mathrm{BaO} \\
\text { (wt.\%) }\end{array}$ & $\begin{array}{l}\mathrm{IrO}_{2} \\
\text { (wt.\%) }\end{array}$ & $\begin{array}{l}\mathrm{WO}_{3} \\
\text { (wt.\%) }\end{array}$ & $\begin{array}{l}\mathrm{OsO}_{4} \\
\text { (wt.\%) }\end{array}$ \\
\hline 3 & Concentration & 5.3 & 20.8 & 0.369 & 0.049 & 0.02 & 1.39 & 1.56 & 70.45 & 0.049 & -- & \\
\hline 5 & Concentration & 6 & 25.88 & 0.369 & 0.049 & 0.02 & 1.39 & 1.56 & 64.7 & 0.049 & -- & \\
\hline 7 & Concentration & 5.7 & 17.6 & 0.516 & 0.027 & 1.39 & 0.021 & 0.021 & 74.5 & & 0.054 & 0.07 \\
\hline 9 & Concentration & 5.7 & 24.391 & 0.516 & 0.056 & 0.052 & 1.39 & 0.021 & 67.75 & & 0.054 & 0.07 \\
\hline 10 & Concentration & 3.8 & 20.8 & 0.433 & 0.052 & -- & 1.55 & 1.56 & 73.32 & 0.058 & -- & 0.03 \\
\hline
\end{tabular}

Table 5: Chemical Composition of barite from a commercial company based in Nigeria.

\begin{tabular}{lcccccccccc}
\hline Element & $\mathrm{K}_{2} \mathrm{O}$ & $\mathrm{Al}_{2} \mathrm{O}_{3}$ & $\mathrm{Fe}_{2} \mathrm{O}_{3}$ & $\mathrm{Na}_{2} \mathrm{O}$ & $\mathrm{SiO}_{2}$ & $\mathrm{SO}_{3}$ & $\mathrm{CaO}$ & $\mathrm{BaO}$ & $\mathrm{MnO}$ & $\mathrm{MgO}$ \\
\hline Content (\%) & 0.06 & 1.29 & 0.52 & 0.07 & 4.53 & 19.48 & 0.08 & 72.04 & 0.01 & 0.02 \\
\hline
\end{tabular}


Mills, L. (2005). Capacity Building in Support of Preparation of Economic Partnership Agreement: Project 110 All ACP-Rules of Origin.

Onyedika, G.O., and Njoku, P. C. (2007). Differential flotation of Nigeria's Galena-Sphalerite ore using Xanthate collector from locally sourced caustic soda. J. Eng. and Appl. Sci., 2(4):745-749.

Onyemobi, O. O., and Nwoko, V. O. (1997). Beneficiation study on a Nigerian barite ore for industrial use. J.Mater. Sci. Techn. 13:76-78.

Raju, G. B.; S. Prabhakar, and S. S. Rao. (2004). Studies on the beneficiation of barite. 322-330
Salisu, A. G.; Y. B. Abba, and Z. Mohammed. (2015). Environmental and health hazards associated with exploration of barite from Bukkuyum (Zamfara State), Nigeria. ISABB Journal of Health and Environmental Sciences, 2(3):11-15.

Ulusoy, U., and Yekeler, M. (2007). Floatability of barite particles with different shape and roughness. Indian Journal of Chemical Technology 14:616-625.

Wang, H. J.; H. X. Dai, W. L. Yang and T. T. Li. (2014). Research on the flotation experiment of a low-grade barite ore in Myanmar. In Applied Mechanics and Materials, Trans Tech Publications, 644:5277-5280).

Wills, B. A. (1981). Mineral Processing Technology. $2^{\text {nd }}$ Edition. Oxford: Pergamon Press. 